\title{
TOXICITY OF ELECTRIC ARC WELDING FUMES
}

\author{
3) Experimental Studies on Welder's Fever (2)
}

\author{
Miyako OHмото $†$, Atsuko Ishimi + , Kazuhide $\mathrm{DoI}^{\dagger}$ \\ and Akira NUKADA $\dagger$
}

熔接 フュームの有害性

3）熔接熱汇関する実験的研究（2）

大本美彌子*, 石見敦子*, 土居一英*, 額 田 薮*

\begin{abstract}
In order to pursue the cause of welding fume-generated fever, rabbits were given fume suspension which was subjected to pretreatments - (1) centrifugation, (2) prolonged storage at room temperature, (3) boiling, (4) heat-desiccation, and (5) freeze-desiccation - and the development of fever was observed. Furthermore, body temperatures, brain temperatures, blood pressures of rabbits and catalase activity in the liver of rats were measured to determine the relation of the fume pyrogen to some of the temperature-regulating factors such as the autonomic nervous system and $\mathrm{Fe}$-related enzymes (magnetic, oxidation-reduction and metal enzymes).

A water-soluble fraction fume suspension failed to develop fever in rabbits, while a waterinsoluble fraction showed pyrogenecity. Thus this pyrogenic agent was relatively thermo-stable, but became inactive when desiccated by heat (freeze-desiccation did not prevent the activity). Rabbits developed fever a few minutes after the administration of lipopolysaccharide, and a rise in brain temperature preceded that of rectal temperature. However, a rise in brain temperature did not precede after fume administration, and the latent period was longer, and the liver catalase activity was somewhat affected. Moreover, the catalase blocker reduced fume-generated pyrexia. It was suggested that the pyrogenic activity of the intravenously injected fumes might not be central but might affect the metabolic mechanism, and that the pyrogenic factor in the welding fume might be changed physically in its structure when heated in dehydrated state, and the pyrogenecity would vanish due to this physical change.
\end{abstract}

\section{INTRODUCTION}

In the first report ${ }^{1)}$ we noted that rabbits developed fever not only upon inhalation but also after the injection of arc welding fumes, and that the fever did not depend much on the kind of welding electrodes, being equally produced with any kind of electrodes which are now in use. It was consequently assumed that alkaline material in the fumes might be directly involved as a pyrogenic agent. In

† Department of Hygiene, School of Medicine, Toho University

Received for publication. June 30, 1975

* 東邦大学医学部衛生学教室 昭和 50 年 6 月 30 日受付 the present report, which aimed to make further research into the cause of the fever, the fumes were preliminarily subjected to various physical treatments and it was investigated whether any change had been elicited in the pyrexial pattern in rabbits. Moreover, physiological, pharmacological and biochemical investigations were carried out to elucidate the mechanism of the development of Welder's fever.

\section{MATERIALS AND METHODS}

Animals: Healthy, adult, male albino rabbits, weighing between 2.5 and $3.0 \mathrm{~kg}$, and healthy normal rats of the wistar strain weighing between 250 and $270 \mathrm{~g}$ were used. 
Fumes suspensions: Low hydrogen type electrodes (three kinds from two makers) were used to make arc on a soft steel plate, and the produced fumes were trapped with an impinger and introduced into distilled water for injection as reported previously by the authors. ${ }^{1)}$

Drugs: Epi (epinephrine-HCl, Daiichi Pharm. Co.), N-Epi (nor-epinephrine- $\mathrm{HCl}$, Sankyo Pharm. Co.), Ach (acetylcholine chloride, Daiichi Pharm. Co.), Atr (atropine- $\mathrm{H}_{2} \mathrm{SO}_{4}$, Torii Pharm. Co.), Dib (dibenamine- $\mathrm{HCl}$, Yoshitomi Pharm. Co.), MJ 1999 (Mead Johnson \& Co.), Reserp. (reserpine, Gevr. Giulini GmBh - Ludwighafen/Rhein), AT (aminotriazol, laboratory made, Tokyo Kasei Co., Ltd.), AIC (allyl-isopropylacetyl carbamide, laboratory made, Tokyo Kasei Co., Ltd.) and LPS (lipopolysaccharide, E. coli, Difco Laboratories) were tested.

The observation of fever development in rabbits was made as described in the first report. ${ }^{1)}$ The fume suspension was intravenously given in the $v$. praeauricularis in doses of $5-10 \mathrm{mg} / \mathrm{kg}$. b.w.

1. Effects of treatments on pyrogenic property of fumes

a) Fractionation by centrifugation: The welding fume suspension was separated into the water-soluble fraction (supernatant) and the water-insoluble part (sediment) being centrifuged at $5,000 \mathrm{rpm}$ for 30 minutes, and both were used to examine the pyrogenecity in rabbits. The sediment was suspended in distilled water in doses of $5-10 \mathrm{mg}$ fumes $/ \mathrm{kg}$ in $2-4 \mathrm{ml} /$ animal (three times as large as the minimal pyrogenic dose), the supernatant was given in doses of $2-4 \mathrm{ml} /$ animal; both the sediment and the supernatant were injected into the $v$. praeauricularis of rabbits.

b) Fractionation through glass filters: Fractionations were performed with Shibata's glass filters nos. 1-5 (with meshes of $0.5 \mu$, $1.5 \mu, 3.0 \mu, 5.0 \mu$ and $10.0 \mu)$. Animal examinations were made in the same way as above described. When the pyrogenecity of the fumes was examined after its direct inhalation, the distribution of the fumes' particle size according to horizontal and vertical distance from the arc was preliminarily determined and an inhalation experiment was made at several places in different distributions of particle size. Also samples of the fume suspension were allowed to stand for various durations after stirring to obtain different waterinsoluble fractions, and the pyrogenecity by the administration of these samples was similarly examined.

c) Prolonged storage: The suspension was stored after the first examination in stoppered tubes at room temperature for six months, and the pyrogenecity was examined again afterwards.

d) Heating: The suspension was heated at $100^{\circ} \mathrm{C}$ for one hour with addition of boiling distilled water to prevent the depletion of water, and after cooling to room temperature, it was injected into rabbits.

e) Desiccation by heating-evaporation: The fume suspension was heated at $120^{\circ} \mathrm{C}$ for one hour or at $150^{\circ} \mathrm{C}$ for 30 minutes to desiccate it sufficiently by evaporation, and the resultant dried powder was suspended in distilled water for injection into rabbits.

f) Freeze-desiccation: The fume suspension was frozen and dried in a sterilized ampule, and then suspended in distilled water for injection into rabbits.

2. The study of pyrogenetic mechanism

a) Measurement of brain temperature: One week prior to measurement, a $\mathrm{Cu}-\mathrm{Co}$ thermocouple was implanted in the routine way into the hypothalamic area (according to the map by C.H. Sawyer et al.), and brain and rectal temperature were simultaneously measured after the administration of welding fumes or LPS.

b) Effects of various drugs

i) Effects of autonomic nerve drugs: Effects of autonomic nerve drugs (Epi, N-Epi, Ach, Atr, Dib, MJ 1999 and Reserp.) on rabbit's rectal temperature and fever development after application of fumes were investigated. Reserp. was given intraperitoneally and the others were injected into the $v$. praeauricularis. The doses were as follows : Epi and N-Epi, 5-10 $\mu \mathrm{g}$; Ach, 1-2 $\mu \mathrm{g}$; Atr, $2 \mathrm{mg}$; Dib, $3 \mathrm{mg}$; MJ 1999, 0. 3-1 mg/kg b.w.

For the observation of their effects on fume-generated fever, Reserp. was given 17 hours before, Atr and Dib five minutes before, Epi, N-Epi and Ach 18 minutes after, and 
Table 1. Pyrogenic activity of pretreated welding fume on rabbits.

\begin{tabular}{lc}
\hline Pretreatment & $\begin{array}{c}\text { Presence or } \\
\text { absence of pyrexia }\end{array}$ \\
\hline Supernatant after centrifug. & - \\
at $1,000-5,000 \mathrm{rpm}$ & + \\
Sediment after centrifug. & + \\
at $1,000-5,000 \mathrm{rpm}$ & + \\
Sediment with larger particles & + \\
Sediment with smaller particles & + \\
Standing at room temperature & + \\
for 6 months & - \\
Heating at $1,000^{\circ} \mathrm{C}$ & + \\
Evaporation-desiccation by & + \\
heating at $120^{\circ} \mathrm{C}$ and $150^{\circ} \mathrm{C}$ & \\
Freezing-desiccation &
\end{tabular}

MJ 199910 minutes after the fume administration. At the same time, their effects on rabbit's blood pressure were investigated.

ii) Effects of liver catalase blockers:

Effects of liver catalase blockers (AT and AIC) on rabbit's rectal temperature were observed in the same way mentioned above.

AIC was given 50-60 minutes before the fume administration in a dose of $200 \mathrm{mg} / \mathrm{kg}$, and AT immediately or 40 minutes after the administration in a dose of $2 \mathrm{~g} / \mathrm{kg}$, both into the $v$. praeauricularis.

c) Assay of catalase activity ${ }^{2)}$ : Rats were injected with $20 \mathrm{mg} / \mathrm{kg} \mathrm{b}$.w. of fumes, and $15,30,60$ and 180 minutes thereafter they were sacrificed to assay the catalase activity in the liver by a modification of Euler and Josephan's method. The assay was also made after the injection of $2 \mu \mathrm{g} / \mathrm{kg}$ b.w. of LPS and saline.

\section{RESULTS}

1. Effects of various conditions on pyrogenecity of welding fumes (Table 1)

a) Effect of fume fractions obtained by centrifugation were as follows: The supernatant obtained after 20 minutes at 5,000 rpm did not develop fever in rabbits, but the sediment did. Also in the case of $3,000 \mathrm{rpm}$ and $1,000 \mathrm{rpm}$ centrifugations, the supernatants failed to exert the effect, while the sediments were effective. Extremely light, minute particles of fumes were visible on the surface of the supernatant, which were similar in color in the sediment. This floating material contained the pyrogenetic agent.

b) Effects of the fractions roughly separated through meshes of the glass filter were as follows: There was no difference in the grade of pyrogenecity between the fractions. Similar results were also obtained by experiments at various parts of an inhalation box adjacent to a fume-producing box, where fume particle sizes were different.

c) The fume suspension obtained with an impinger was twice given to rabbits, it was found by the bioassay that after being allowed to stand at room temperature for more than six months the fumes perfectly reduplicated the pyrexic pattern which was produced by the suspension immediately after its preparation.

d) Heating at $100^{\circ} \mathrm{C}$ did not elicit any change in the pyrexic effect of the fume suspension.

e) Heating evaporated-desiccation at $120^{\circ} \mathrm{C}$ for one hour or heating at $150^{\circ} \mathrm{C}$ for 30 minutes completely abolished pyrexic effect of the fume suspension on rabbits.

f) The freezing-desiccated fume suspension induced the same pyrexic effect on rabbits as the non-treated fumes.

2. The study of pyrogenetic mechanism

a) Change in brain temperature: When LSP was injected into rabbits, temperature elevation occurred in the brain in two minutes, followed by that in the rectum a little later. After fume injection, the temperature rose in the rectum in 20 minutes, and then in the brain.

b) Effects of various drugs (Table 2)

i) Autonomic nerve drugs: Injections of Adr, Ach, Dib or MJ 1999 did not produce any change in body temperature of the rabbit, nor exert any effect on pyrogenetic activity of the fume suspension on rabbits. Atr, which by itself slightly elevated the body temperature of rabbits, never enhanced the pyrogenetic effect of the fumes on rabbits. Reserp., which by itself markedly lowered the body temperature of rabbits, suppressed the temper- 
Table 2. Effects of various drugs on fever development of rabbits and on pyrogenicity of fume.

\begin{tabular}{|c|c|c|c|c|}
\hline \multirow[b]{2}{*}{ Drugs } & \multirow[b]{2}{*}{$\begin{array}{c}\text { Dose } \\
\text { (/kg. b.w.) }\end{array}$} & \multicolumn{3}{|c|}{ Rabbit's fever development } \\
\hline & & $\begin{array}{l}\text { By drug } \\
\text { itself }\end{array}$ & $\begin{array}{l}\text { In combination } \\
\text { with fume sus- } \\
\text { pension }\end{array}$ & $\begin{array}{l}\text { In combination } \\
\text { with LPS }\end{array}$ \\
\hline Epinephrine & $5-10 \mu \mathrm{g}$ & $\longrightarrow$ & $\left(\begin{array}{l}\mathbf{t} \\
\mathbf{\uparrow}\end{array}\right)$ & $\left(\begin{array}{l}\mathbf{t} \\
\mathbf{t}\end{array}\right)$ \\
\hline Nor-epinephrine & $5-10$ & $\longrightarrow$ & $\left(\begin{array}{l}\mathbf{t} \\
\mathbf{t}\end{array}\right)$ & $\left(\begin{array}{l}\mathbf{t} \\
\mathbf{t}\end{array}\right)$ \\
\hline Nor-epinephrine & 200 & $\uparrow$ & $\stackrel{t}{\uparrow}$ & $\stackrel{t}{t}$ \\
\hline Acetylcholine & $1-2$ & $\longrightarrow$ & $\left(\begin{array}{l}\mathbf{t} \\
\mathbf{t}\end{array}\right)$ & $\left(\begin{array}{l}\boldsymbol{\uparrow} \\
\mathbf{t}\end{array}\right)$ \\
\hline Atropine & $2 \mathrm{mg}$ & $\uparrow$ & $\left(\begin{array}{l}\mathbf{t} \\
\mathbf{t}\end{array}\right)$ & $\left(\begin{array}{l}\boldsymbol{t} \\
\mathbf{t}\end{array}\right)$ \\
\hline Atropine & 20 & $\uparrow$ & $\boldsymbol{\uparrow}$ & $\boldsymbol{t}$ \\
\hline Dibenamine & 3 & $\longrightarrow$ & & \\
\hline MJ-1999 & $0.3-1$ & $\longrightarrow$ & & \\
\hline Reserpine & 5 & $\downarrow$ & $\uparrow$ & $\longrightarrow$ \\
\hline AIC & 200 & $\longrightarrow$ & $\uparrow$ & \\
\hline $\mathrm{AT}$ & $1 \mathrm{~g}$ & $\downarrow$ & $\left(\begin{array}{l}\mathbf{t} \\
\mathbf{t}\end{array}\right)$ & \\
\hline
\end{tabular}

( $\uparrow$ ): Unaffected by drugs.

ature elevation caused by the fumes to about one-third and completely inhibited the pyrogenetic effect of LPS when given beforehand. Both Atr and N-Epi, in tenfold doses, elevated the body temperature.

Surgical observation of carotid blood pressure of rabbits revealed that the fume suspension produced only transient fall. LPS elicited scarcely any change.

ii) Catalase blockers: AT by itself produced almost no change in the body temperature, while AIC caused slight drops in the body temperature. AT suppressed the fumes' pyrogenetic activity to one-half in rabbits.

c) Examination of catalase activity of rats' liver homogenate after their sacrifice at 30, 60 and 180 minutes following the administration of the fume suspension and of LPS revealed no difference from the control. However, the activity was higher than in the control 15 minutes after the administration of fumes. The liver catalase level in rats was lower than in the control 30 minutes after AT administration.

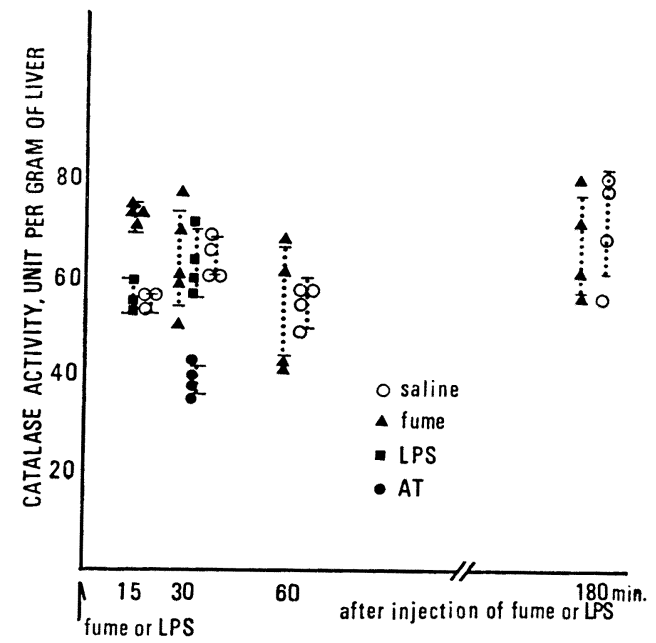

Fig. 1. Liver catalase activities in rats, pretreated with welding fume, LPS, AT and saline.

\section{DISCUSSION}

It was previously reported ${ }^{1)}$ that fever was developed by the fumes in rabbits no 
matter whether the low-hydrogen type or nonlow-hydrogen type electrode was used, and therefore the $\mathrm{pH}$ of fume suspension in distilled water (hereafter referred to only as fume suspension) would not have any bearing on the fumes' pyrogenecity in rabbits.

The present experiment elucidated that the fumes allowed to stand at room temperature for more than six months after collection became nearly neutral, loosing alkalinity which they had immediately after the collection nevertheless they demonstrated the pyrogenecity to the same degree as the initial one. And the assumption, that the fumes' pyrogenecity may not be dependent on its $\mathrm{pH}$, was again confirmed. Another assumption, that the fumes' pyrogenic agent may not be bacterial, as was clearly suggested by the pyrexic pattern in the previous work ${ }^{1)}$ was also corroborated by the present findings: The fumes after standing for more than six months still retained pyrogenecity and desiccation by heating at $120^{\circ} \mathrm{C}$ and $150^{\circ} \mathrm{C}$ completely prevented this activity and the supernatant after centrifugation at low speed failed to develop fever. Bacterial pyrogen can not be perfectly inactivated unless it is heated at $250^{\circ} \mathrm{C}$ for 30 minutes, and its pyrogenic agent will be contained in the supernatant obtained by lowspeed centrifugation. And if the pyrogen in question was bacterial, it would not withstand more than six months in such an unfavorable medium.

In respect to the question if the pyrogen is metalic the present experiment disclosed that the heating in the absence of water, i.e., desiccation by heating, prevented the pyrogenecity, while desiccation by freezing or heating in the presence of water did not affect it. This suggests a possibility that the effect of heating on the lattice structure of a metal compound may be affected by the absence of water. There was a considerable difference in electron microscopic observations between the results of heating-dried and the freezingdried treatment of fumes suspensions. There was also a difference between the previous finding that $\mathrm{ZnO}$ and other metal oxides prepared in the laboratory were pyrogenetic and the parchased $\mathrm{ZnO}$ and other metal oxides of commercial preparations, were not pyrogenet-

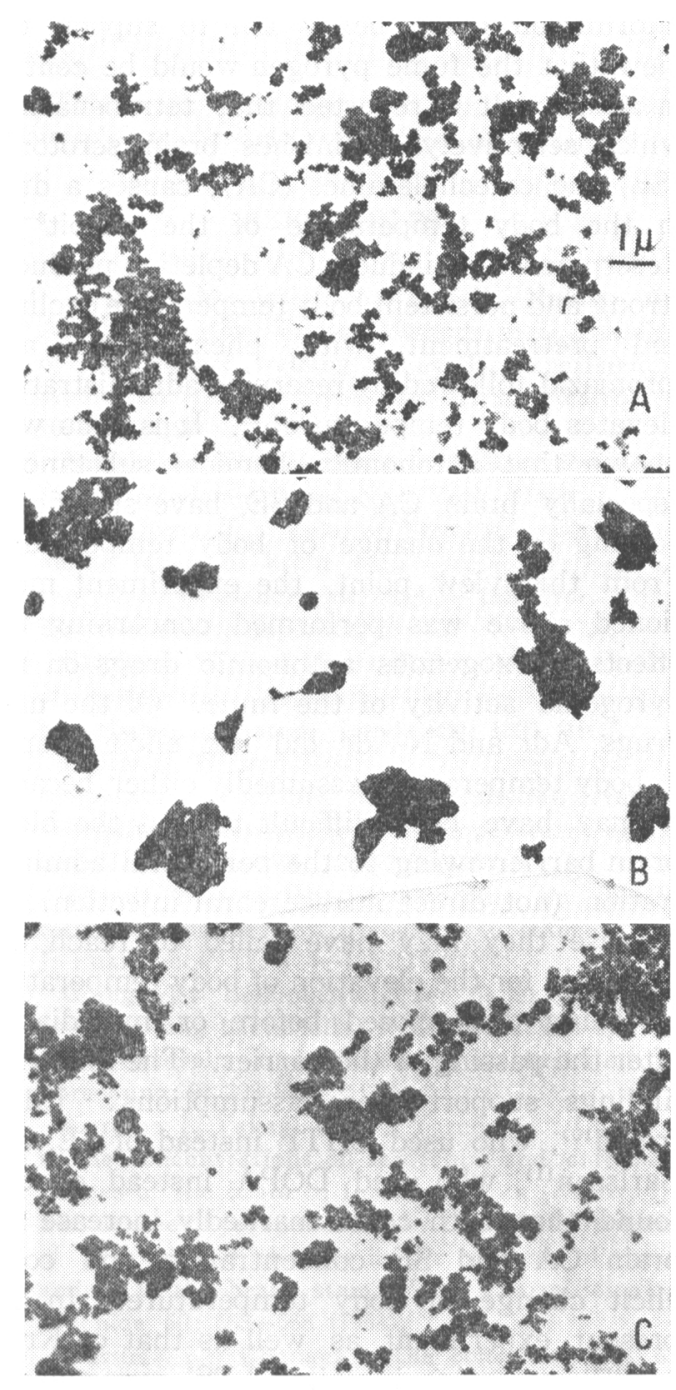

Fig. 2. Electron microscopic pictures of fume after pretreatments:

A. Heating at $100^{\circ} \mathrm{C}$ for one hour, B. heat desiccation at $150^{\circ} \mathrm{C}$ for one hour, C. freezedesiccation.

ic, previously. Further studies must be perfomed for elucidation on these points.

It is known that the central pyrogen elicits changes in brain temperature as well as in EEG and brain metabolism before the production of systemic fever. In the case of fume-derived pyrexia, the rise of temperature in the brain did not precede that in the rectum. The difficulty in producing resistance as reported in the previous paper ${ }^{1)}$ and the 
information given below fail to support the view that the fume pyrogen would be central in action: It is reported that tetrabenazine, which selectively diminishes brain serotonin (SE) and catecholamines (CA), causes a drop in the body temperature of the rabbit $^{3-7)}$; Reserpine which induces CA depletion produces strong and persistent body temperature decline, and pretreatment with pheniprazine and iproniazid followed by reserpine administration elevates body temperature ${ }^{8,9)}$. It is thus well known that autonomic chemical substances, especially brain $\mathrm{CA}$ and $\mathrm{SE}$, have significant bearing on the change of body temperature. From this view point, the experiment mentioned above was performed concerning the effects of exogenous autonomic drugs on the pyrogenic activity of the fume. Of the used drugs, Adr and N-Adr did not elicit change in body temperature, assumedly either because it may have been difficult to pass the blood brain barrier owing to the peripheral administration (not direct intracerebral injection), or because they may have failed to reach the threshold for the elevation of body temperature by being decomposed before or immediately after the passing of the barrier. The following findings support these assumptions: Udenfriend $^{10)}$, who used 5HTP instead of SE, and Carlsson ${ }^{11)}$, who used DOPA instead of CA, found that both could markedly increase the brain $\mathrm{CA}$ and SE concentration and could elicit change in body temperature. In the present experiment as well as that of Kronberg $^{12)}$, reserpine inhibited LPS' pyrogenecity but did not inhibit the fumes' pyrogenecity completely.

Out of the metal components of arc welding fumes, $\mathrm{Fe}$ found in the form of oxide is the largest in proportion. On the other hand, many oxidation-reductases related to the metabolic system, for example, cytochrome, per-oxidase, catalase and others contain $\mathrm{Fe}$. In order to elucidate the action of welding fumes in the metabolic system, catalase activity was measured in the present experiment.

The catalase activity in the rat's liver was not different from that of the control at 30,60 and 180 minutes after the administration of fume, but it was found to be elevated at 15 minutes. Also the effect upon rabbit body temperature of a drug which inhibits the catalase activity was investigated: As far as the authors know, there is no report on this point. The catalase blocker would exert some effects on rabbit's body temperature, since, as mentioned above, catalase activity was elevated early after the pretreatment of the animal with welding fumes. And it was observed that AIC, which by itself slightly lowered the body temperature, did not inhibit the elevation of the body temperature caused by the fumes, while AT, which by itself did not elicit any change, considerably inhibited the rise of body temperature after pretreatment with the fumes. As for the action mechanisms of AIC and AT, it is known that the former impedes catalase synthesis ${ }^{13)}$ and the latter inactivates it after reaction with a cofactor in the liver. ${ }^{14)}$ It is consequently assumed that the pyrogenic agent in the fumes may not directly participate in catalase synthesis, but that it may directly or indirectly be involved in the activation of catalase, or that it may exert antagonistic influence on some unknown action of AT. Further studies will be required in order to clarify these possibilities.

The phenomenon of "pyrexia" is a systemic reaction, and the pyrexic mechanism involves all the factors affecting elevation of body temperature, including the peripheral as well as the central.

In the beginning it was assumed that metal fumes might be involved in the pyrexia by being incorporated in the metal enzyme during its biosynthesis. But judging from the results, metal fumes seem to accelerate energy production by acting as a biocatalyser. If so, it is probable that the fumes may induce hyperfunctions in various systems, and that their summation may result in the phenomenon of pyrexia. Beeckmans ${ }^{15}$ ) reported in respect to metal toxicity that $\mathrm{ZnO}$ treated with ultraviolet light irradiation increased the toxicity to animals.

It is said that the second peak of fever, produced by bacterial pyrogen LPS, is visible when the so-called leucocytic pyrogen is formed at the time of the second peak, after causing formation of polynuclear leucocytes, and therefore that it takes several hours before the formation of this peak. In the case 
of the administration of fumes, fever developed in 20 minutes, earlier than the appearance of the second peak of LPS. It seems, therefore, that the fumes may elicit a change somewhere in the process of body temperature rise, and then may possibly trigger central amine release, although brain CA after fume administration was not assayed.

\section{SUMMARY}

In order to elucidate the pyrogenic agent of welding fumes, rabbits were given fume suspension which had been subjected to various physical pretreatments, and the development of fever was observed. Body temperatures, blood pressures and catalase activities in the liver were measured to determine the relation of the fume pyrogen to some of the temperature-regulating factors such as the autonomic nervous system and Fe-related oxidation-reductase. The results obtained were as follows:

1) A water-soluble fraction of the fumes obtained by suspending the fumes in distilled water by means of an impinger failed to develop fever in rabbits.

2) The fumes collected into an impinger did not lose pyrogenetic activity, (i) when allowed to stand in a stoppered tube at room temperature for six months, or (ii) when boiled, or (iii) when freeze-dried. But (iv) desiccation by heating prevented pyrogenecity.

3) The change in brain temperature after administration of fumes did not precede that in rectal temperature.

4) The fume-derived pyrexia was inhibited in reserpine- or AT-pretreated animals.

5) Liver catalase activity was elevated at 15 minutes after fume administration more than that in controls which had been given saline or LPS.

6) Judging from the present results, it was assumed that the pyrogenetic action of welding fumes injected intravenously might not be central, but somehow related, as metallic enzyme or catalyser, to the metabolic system, that is, related, as a metal or a metal compound to the oxidation-reduction system. And its pyrogenic agent became inactive after heat-desiccation, which would possibly have altered the lattice crystal structure of the agent.

(This work was supported by the Education Ministry's grant-in-aid for development research.)

\section{REFERENCES}

1) Ohomoto, M., Ishimi, A.. Doi, K., Nukada, A., Akashi, S., Mori, T. and Matsuda, A.: Toxicity of electric arc welding fumes (I). Experimental studies on welder's fever, Jap. J. Ind. Health, 16: 103-112 (1974).

2) Nakahara, W.: Methods in Cancer Research, II, 203, Academic Press, New York (1967).

3) Takashima, T.: Relation between pyrexia and amine levels in brain with special reference to the action of monoamine oxidase inhibitor, Folia Pharmacologica Japonica, 58: 437-448 (1962).

4) Feldberg, W. and Myers, R.D.: A new concept of temperature regulation by amines in the hypothalamus, Nature, Lond.. 200: 1325 (1963).

5) Feldberg, W. and Myers, R.D.: Effects on the temperature of amines injected into the cerebral ventricles, A new concept of temperature regulation, J. Physiol., 173: 226-237 (1964).

6) Yasuda, M.: Effect of reserpine on febrile responses induced by pyrogenic substances, Jap. J. Pharmacol., 11: 114-125 (1962).

7) Göing, H.: Beeinflussung der fieber erzengenden Wirkung bacterieller Pyrogene durch Iproniacid, Reserpin und Dibenamine, Arzneimittel Forschung, 9: 793-794 (1959).

8) Kuruma, I., Takagi, H. and Yasuda. H.: Changes in the concentrations of serotonin and catecholamines of the brain in febrile rabbits (Report I), The degree of fever induced by the administration of pyrexal and changes in the contents of these amines in the brain stem, Folia Pharmacologica Japonica, 60: 563-568 (1964).

9) Kuruma, I.: Changes in the concentrations of serotonin and catecholamines of the brain in febrile rabbits (Report II), The influence of high ambient temperature on the concentration on the rabbits brain stem, Folia Pharmacologica Japonica, 62: 8-10 (1966).

10) Udenfriend, S., Weissbach, H. and Bogdanski, D.F.: Increase in tissue serotonin following administration of its precursor 5- hydroxy tryptophan, J.B.C., 224: 803-811 (1957).

11) Carlsson, A.: The occurrence, distribution and physiological role of catecholamines in the nervous system, Pharmacol. Rev., 11: 490-493 (1959).

12) Kroneberg, G. und Kurbjuweit, H.G.: Die Beeinflussung von experimentellem Fieber durch Reserpin und Sympathicolytica am Kaninchen, Arzneimittel Forschung, 9: 556-558 (1959).

13) Sugimura, T.: The mechanism of liver catalase depression by 3-amino-1.2.4-triazole, Gann, 47: 159 -170 (1956).

14) Price, V.E., Sterling, W.R. and Talanta, V.A.: The kinetics of catalase synthesis and destruction 
in vivo, J.B.C., 237 : 3468-3475 (1962).

15) Beeckmans, J.M. and Brown, J.R.: Toxicity of catalytically active zinc oxides, Archives of Environmental Health, 7: 346-350 (1963).

\section{和文 要 旨}

熔接フュームによる発熱の原因を追求するため, 熔接 フューム懸濁液に (1)遠心分離，(2)室温長期間放置，(3) 煮沸, (4)加熱乾燥, (5)凍結乾燥などの処置を施し, これ らについて家鬼発熱性を観察した。また，体温調節に関 連ある多くの諸因子のうち，自律神経系拈よび Fe 関連 酵素 (magnetic, oxidation-reduction, metal enzyme 等）との関連の検索を行ならため体温, 脳温, 血圧, catalase 活性等を測定した. 愹接フューム愳濁液の水可 溶性分画は家鬼に対し発熱させる作用はなく, 水不溶性 分画は家鬼に対し発熱を起こさせ，この発熱を起こさせ
る因子は，熱に対し比較的安定であるが加熱による乾燥 によってその発熱性を失う(凍結乾燥法による乾燥によ っては発熱性を失わない).

また LPS は投与後数分の滥伏期をもち発熱，乙かも 脳温が直晹温に先行して上是与るのに対しフュームの場 合は脳温は先行せず，潜伏期も20分と長く，朋 catalase 活性にもやや影暗をもたらし，また朋 catalase 活性低 下作用物質によりフュームの発熱が減少するなど，熔接 フューム静脈内投与による発熱は中枢性ではなく，金属 フェームの生体内代射機蓝への働きかけが示唆されるよ うな結果が得られた。また，熔接フューム中の発熱に関 連する⿴子は, 水分不存在状態での加熱によりその構造 中に物理的変化を受け，この変性により発熱性が失われ るものと思われる。 